\title{
Effects of fisheries closure size, age, and history of compliance on coral reef fish communities in the western Indian Ocean
}

\author{
Tim R. McClanahan ${ }^{1, *}$, Nicholas A. J. Graham ${ }^{2,3}$, Shaun K. Wilson ${ }^{3,4}$, \\ Yves Letourneur ${ }^{5}$, Rebecca Fisher ${ }^{6}$ \\ ${ }^{1}$ Marine Programs, Wildlife Conservation Society, 2300 Southern Boulevard, Bronx, New York 10460, USA \\ ${ }^{2}$ School of Marine Science and Technology, Newcastle University, Newcastle upon Tyne, NE1 7RU, UK \\ ${ }^{3}$ ARC Centre of Excellence for Coral Reef Studies, James Cook University, Townsville, Queensland 4811, Australia \\ ${ }^{4}$ Department of Environment and Conservation, 17 Dick Perry Ave, Kensington, Western Australia 6151, Australia \\ ${ }^{5}$ Centre d'Océanologie de Marseille, Université de la Méditerranée, Campus de Luminy, Case 901, 13288 Marseille cedex 09, \\ France \\ ${ }^{6}$ Australian Institute of Marine Science, UWA Oceans Institute (M096), 35 Stirling Hwy, Crawley, Western Australia 6009 ,
} Australia

\begin{abstract}
The hypothesis that the history of management compliance (strong versus variable), closure size ( 0.3 to $28 \mathrm{~km}^{2}$ ), closure age (2 to $39 \mathrm{yr}$ ), and habitat/geographic variables influenced total fish biomass, the number of species, and the ratio of herbivores to carnivores in no-take areas was tested. Twenty existing closures across 6 countries in the western Indian Ocean were sampled during the same time period (2004 to 2007). Geographic location and closure attributes were weak to moderate predictors of these coral reef fish community variables for analyses of all closures. Strong interactions between fish community variables and levels of compliance indicated that high compliance sites largely drove the closure-fish community relationships. Variable or weak compliance and closures $<1 \mathrm{~km}^{2}$ exhibited limited recovery of fish communities. The closure area-fish biomass data for strong-compliance closures indicates that biomass is stable above $5 \mathrm{~km}^{2}$. A mix of communitybased, private, and national program closures were sampled, and, although low sample sizes within each of these management systems precludes conclusive analysis, none of these management systems was universally successful in terms of compliance or maximizing fish community variables.
\end{abstract}

KEY WORDS: East Africa · Island biogeography $\cdot$ Marine protected areas $\cdot$ Marine fisheries reserves • Private parks $\cdot$ Protected area management $\cdot$ Resilience

Resale or republication not permitted without written consent of the publisher

\section{INTRODUCTION}

Empirical studies of fishery closure design can assist in understanding the effects of management compliance, the potential for timing of permanent, periodic, or rotational closures, and appropriate sizes for the purpose of recovery, enhancing spillover of fish, and protecting key species with large spatial needs (Halpern \& Warner 2003). Consequently, the importance of marine fishery closure design in sustaining fish populations and fisheries has led to considerable theoretical and modeling attention (Rothley 1999, Sladek-Nowlis \& Roberts 1999, Roberts et al. 2001, Rodwell et al. 2002, Sala et al. 2002,
Halpern \& Warner 2003, Leslie et al. 2003, Shanks et al. 2003, Micheli et al. 2004a, Gaylord et al. 2005, Baskett et al. 2007, Kulbicki et al. 2007). Further, meta-analyses of the growing number of field-based studies of marine fisheries closures have been conducted (Côté et al. 2001, Halpern \& Warner 2002, Halpern 2003, Micheli et al. 2004b, Claudet et al. 2008, Lester et al. 2009, Stockwell et al. 2009). Meta-analyses provide empirical tests of theory, but the importance of design factors, such as size and spacing of fishery closures, are often not clearly elucidated because meta-analyses have combined studies from disparate biogeographical, ecological, social, and management environments. 
Meta-analyses have the potential to obscure patterns that might be specific to local geography, ecology, and management. For example, global meta-analyses of the response of fish communities or targeted species to the time of closure have shown insignificant to weak relationships (Côté et al. 2001, Halpern \& Warner 2002, Micheli et al. 2004b), whereas stronger and more predictable relationships have been found when evaluating specific reef locations and ecosystems, such as the coral reefs of the Philippines (Russ \& Alcala 2004, Russ et al. 2005, Stockwell et al. 2009) and Kenya (McClanahan \& Graham 2005, McClanahan et al. 2007a), and temperate European rocky reef ecosystems (Claudet et al. 2008). The role of closure size was also found to be weak based on meta-analyses (Côté et al. 2001, Halpern 2003), and is an aspect of marine reserve design that is currently poorly understood (Lester et al. 2009). Conversely, size, age of the closure, and the existence of buffer zones were found to be important in a meta-analysis of European fishery closures (Claudet et al. 2008). Investigators have noted the possible importance of management effectiveness, fishing intensity, and buffers around closures (Côté et al. 2001, Micheli et al. 2004b, Claudet et al. 2008). These findings highlight the need for more empirical tests of the management and design factors that influence fishery closures from single regions and ecosystems.

The usefulness of some studies has been hindered by the inability to identify and then study sufficient numbers of ecologically similar, high compliance closed areas of variable size and age (Sale et al. 2005, McClanahan et al. 2007a). Additionally, it is often personal experience that allows investigators to know the effectiveness of closure management, as managed areas often suffer from poor compliance and are influenced by a variety of socio-economic factors (Pollnac et al. 2001, McClanahan et al. 2006a, Tobey \& Torell 2006, Walmsley et al. 2006, Christie \& White 2007). Here we examined the effects of management compliance and spatial and temporal closure variability for most of the existing coral reef fisheries closures in the western Indian Ocean (see Fig. 1, Table 1). The hypotheses that management compliance, size, and age influence the total biomass, species richness, and the herbivore:carnivore ratio were tested for 20 coral reef fisheries closures. The possibly confounding effects of coral cover, structural habitat complexity, and geographic location were also assessed.

\section{MATERIALS AND METHODS}

Study sites. Twenty no-take coral reef closures were identified in 6 western Indian Ocean countries (Fig. 1). These closures ranged in terms of surface area and

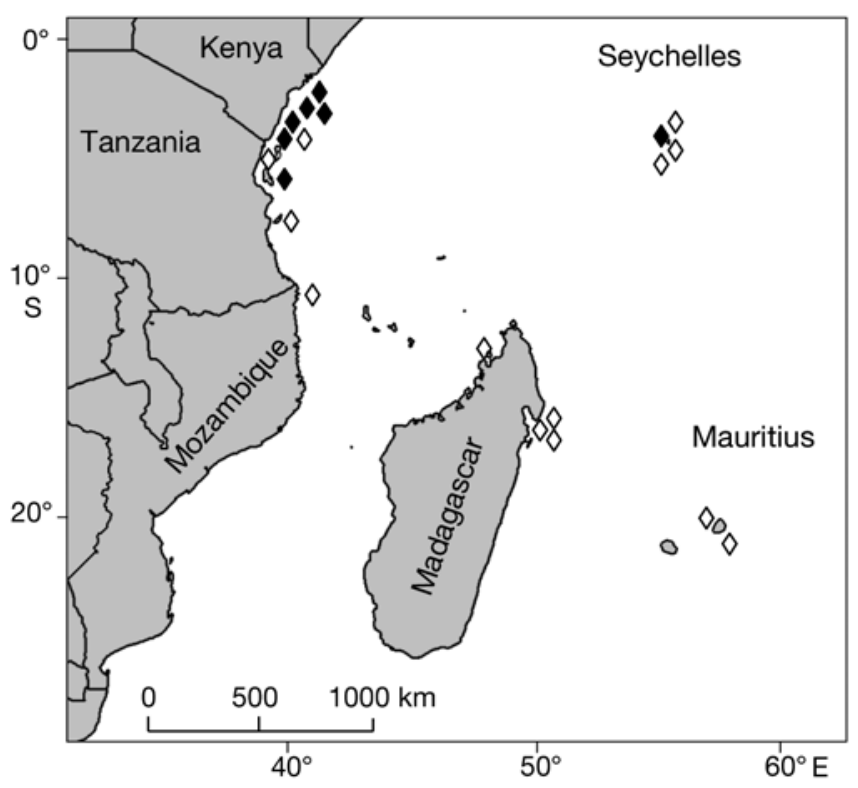

Fig. 1. Study regions and sites in the western Indian Ocean. Filled diamonds: closures with strong compliance; open diamonds: closures with variable or weak compliance. See Table 1 for compliance definitions

time since closure from fishing (Table 1). Closure areas ranged from 0.3 to $28 \mathrm{~km}^{2}$ and in age of closure from 2 to $39 \mathrm{yr}$. They differed in terms of the management organization from those strongly enforced through topdown control, such as 4 Kenyan Marine Protected Areas (MPAs; McClanahan \& Graham 2005) to small, privately owned, well-enforced closures, with $24 \mathrm{~h}$ vigilance, such as Cousin Island Special Reserve (owned by BirdLife International) in the Seychelles (Jennings 1998) and the privately-owned Chumbe Island in Tanzania (Horrill et al. 2000). The above closures and a small community-based closure in Kenya (Kiruwitu), which employs guards, were classified as having strong compliance. The compliance of the remaining closures was variable, with strongly suspected, known, and recorded instances of poaching (McClanahan et al. 1999, 2006b, Walley 2004, Wood 2004). Although some of these closures were moderately effective (Jennings et al. 1995, Graham et al. 2007), the 20 closures were divided into those known to be strongly enforced and those where compliance was variable, weak, or not well-known because compliance was not quantified.

Small differences in fishing can substantially affect depletion of fish biomass, particularly for carnivorous fishes (Jennings \& Polunin 1996, Kulbicki et al. 2007, Stevenson et al. 2007, Sandin et al. 2008). Therefore, to examine the influence of compliance, all closures that had strong and variable or unknown compliance were analyzed both cumulatively and independently. To as- 
sess the importance of compliance, the amount of variance explained by age and size models was compared, both with and without consideration to compliance.

Field methods. Data on fish wet weight and species richness were collected using underwater visual census. All sites were located in the center of the closures on shallow reef flats and slopes of fringing reefs $(<10 \mathrm{~m}$ depth) that were not directly exposed to wave action and, therefore, represent a common shallow-water physically undisturbed habitat. Common diurnally active, non-cryptic, reef-associated fish were counted and their size estimated at each site. In Kenya, Tanzania, Mauritius, and Madagascar, 3 to 5 belt transects $(100 \times 5 \mathrm{~m})$ were used (covering 1500 to $\left.2500 \mathrm{~m}^{2}\right)$ to count and estimate the numbers and size of fish (McClanahan 1994). In the Seychelles, $7 \mathrm{~m}$ radius point counts $\left(\mathrm{n}=16\right.$, covering $\left.2464 \mathrm{~m}^{2}\right)$ were completed in each closure (Graham et al. 2007). In both cases, fish

Table 1. Fisheries closures studied within the Western Indian Ocean. Strong compliance closures are those with continual policing since establishment, closures with variable compliance are those where wardens or guards were not always on site or there was a known history of significant poaching. Based on data from McClanahan \& Graham (2005), J. Church (pers. comm.), Cooke et al. (2003), IUCN (2004), and Jennings et al. (1996). If a nongovernmental organization (NGO) shared establishment and some management responsibility, the management was listed as National/NGO

\begin{tabular}{|c|c|c|c|c|}
\hline Closure & Compliance & $\begin{array}{c}\text { Year } \\
\text { established }\end{array}$ & $\begin{array}{l}\text { Area } \\
\left(\mathrm{km}^{2}\right)\end{array}$ & Management \\
\hline \multicolumn{5}{|l|}{ Kenya } \\
\hline Kisite & Strong & 1973 & 28 & National \\
\hline Kuruwitu & Strong & 2005 & 0.4 & Community \\
\hline Malindi & Strong & 1968 & 6.3 & National \\
\hline Mombasa & Strong & 1991 & 6 & National \\
\hline Watamu & Strong & 1972 & 10 & National \\
\hline Mkokoni Bay & Variable & 2001 & 2 & National/NGO \\
\hline \multicolumn{5}{|l|}{ Madagascar } \\
\hline Nosy Tanikely & Variable & 1968 & 1.0 & Regional \\
\hline Tampolo & Variable & 2001 & 2.0 & National/NGO \\
\hline Masoala & Variable & 2001 & 3.0 & National/NGO \\
\hline Tanjona & Variable & 2001 & 4.0 & National/NGO \\
\hline \multicolumn{5}{|l|}{ Mauritius } \\
\hline Balaclava & Variable & 2003 & 5.0 & National \\
\hline Blue Bay & Variable & 2000 & 3.5 & National \\
\hline \multicolumn{5}{|l|}{ Mozambique } \\
\hline Vamizi & Variable & 2007 & 5 & $\mathrm{NGO}$ \\
\hline \multicolumn{5}{|l|}{ Seychelles } \\
\hline Baie Ternay & Variable & 1979 & 0.8 & National \\
\hline Cousin & Strong & 1968 & 1.2 & Private \\
\hline Curieuse & Variable & 1979 & 10.8 & National \\
\hline Ste Anne & Variable & 1973 & 10.0 & National \\
\hline \multicolumn{5}{|l|}{ Tanzania } \\
\hline Chumbe & Strong & 1994 & 0.3 & Private \\
\hline Mafia & Variable & 1995 & 11.0 & National/NGO \\
\hline Tanga-Makome & Variable & 2000 & 1.0 & National/NGO \\
\hline
\end{tabular}

were surveyed sequentially, with more mobile species counted first, to avoid double counting of individuals. Data from individual replicates were pooled to common sampling areas of $500 \mathrm{~m}^{2}$ to account for the differences in the sampled area per replicate between the 2 methods. Methodological studies have shown that belt transects and point counts produce comparable results (Watson \& Quinn 1997, Samoilys \& Carlos 2000), although not when time was held constant for different sampling areas (Colvocoresses \& Acosta 2007). Time to complete transects was not held constant in our methods but was adjusted according to the mbers of fish in the sampled areas, such that sample e increased with fish density. Different observers eyed the sites, but the influence of observer bias in total underwater fish count variance (Williams et al. 2006, McClanahan et al. 2007b, MacNeil et al. 2008). Nonetheless, we examined and compared the distributions of data collected by the 2 methods.

Wet weight or biomass of individual fish was calculated using estimated length data and length-weight relationships (Letourneur et al. 1998, Froese \& Pauly 2008) and multiplying by abundance of the species or family of fish (McClanahan \& Kaunda-Arara 1996). The ratio of the biomass of herbivores (Acanthuridae, Scaridae, and Siganidae) versus carnivores (Haemulidae, Lethrinidae, Lutjanidae, and Serranidae) was calculated to assess how this metric fluctuates according to closure compliance, age, and size. The highestlevel carnivores, such as sharks, were rarely seen and were not counted in these surveys. Species richness of the fish community was calculated as the sum of all species from 4 families that were comprehensively surveyed at all sites and was standardized and expressed as the number of species $500 \mathrm{~m}^{-2}$. The families surveyed were among the most speciose and included Acanthuridae, Chaetodontidae, Labridae, and Scaridae. This subset is expected to be a useful proxy for estimates of the total number of species present (Allen \& Werner 2002).

Habitat at each site was assessed by estimating coral cover and rugosity. Coral cover was estimated visually as the percent cover at Seychelles sites and with $10 \mathrm{~m}$ line intercept transects at 
other sites. These 2 methods give very similar estimates of coral cover, so the results are therefore suitable for statistical comparison (Wilson et al. 2007). Rugosity at each site was calculated as the linear distance covered by a chain or weighted rope fitted to the reef contour, sensu Risk (1972).

Data analyses. Habitat and geography account for significant amounts of variation in the distribution and abundance patterns of coral reef fish (Munday 2002). Consequently, the assessment of marine park design and effectiveness needs to consider the influence of these variables (Allen \& Werner 2002, Russ 2002, Halpern 2003, Ortiz \& Tissot 2008). Trends and relationships within the fisheries closures with the above variables were examined rather than control-impact relationships between closures and fished areas. Hence, the effect of closure compliance, size, and age were examined while simultaneously assessing the influence of habitat and geography within the closure. The current geographic distribution of coral reef species in this region is crudely understood, and large differences among the study regions have not been reported (Allen 2008); however, we expected islands and mainlands to differ due to oceanographic conditions, fishing, and their history as well as latitudinal patterns of diversity along the African coastline with a maximum diversity expected in Tanzania (McClanahan \& Obura 1996). All predictor variables were assessed for auto-correlation prior to analyses. The only significant correlations were between closure age and coral cover and between age and latitude. In both cases, this was likely due to the north-south spatial patterns of the impacts of the 1998 bleaching event in the region (Maina et al. 2008).

Closure data were analyzed cumulatively using all closures, and separately using the 2 subsets of strong and variable compliance sites. The cumulative analysis used a generalized additive model (GAM) with smoothers to assess the importance of closure attributes on dependent variables (fish biomass, numbers of species, and herbivore:carnivore ratios). Models were originally constructed considering the 3 management attribute variables of primary interest (compliance, closure size, and age). Interactions between compliance and size as well as compliance and age were investigated by allowing different shaped relationships for each dependent variable with strong and variable compliance, which is a property of the GAM method. Models were compared by their Akaike information criterion (AIC) values, and the best model was selected based on the lowest AIC value and fewest variables. Models were considered to be significantly different when AIC values differed by $>2$ units. The low number of closures prohibited simultaneous inclusion of all variables and environmental factors, and precluded the use of a backward step-wise model selection approach.
Instead, AIC was used to select the best single and 2 variable models for each fish response variable.

For the analyses based on the 2 subsets of compliance closures and to visualize the size and age patterns, 4 potential trajectories of biomass and numbers of species were tested based on ecological and closure theory (MacArthur \& Wilson 1967): linear $(y=a x+b)$, $\operatorname{logarithmic}\left(y=\mathrm{a} \log _{10} x\right)$, power $\left(y=\mathrm{a} x^{\mathrm{b}}\right)$ and secondorder polynomial $\left(y=\mathrm{a}_{1} x^{2}+\mathrm{a}_{2} x+\mathrm{b}\right)$. These models were compared to distinguish between linear, saturation, and unimodal relationships with closure size and age, which are common ecological recovery trajectories (Rosenzweig 1995). Trends were tested for biomass, numbers of species, and the ratio of herbivores to carnivores using these model trajectories against both size of closure $\left(\mathrm{km}^{2}\right)$ and age of closure (years), as well as key environmental variables; coral cover, rugosity, latitude, and longitude. The $F$ statistic for each model was calculated as the regression mean divided by residual mean square values. Associated p-values were calculated and used to assess whether models explained a significant amount of variation in the data. Models were compared using AIC to determine the most parsimonious model (Burnham \& Anderson 2002).

To examine any potential systematic bias introduced by the 2 different survey techniques (point counts versus transects), 95\% confidence limits were constructed around the mean of the residual fit to the best model for each survey technique. In each case, mean residual values with $95 \%$ confidence intervals did not differ from 0 , indicating that points were evenly distributed about the best-fit model and were representative of the broader dataset. Examination of scatterplots also suggested that data collected using point counts were not outliers and did not drive the observed patterns. Analyses were carried out using $\mathrm{R}$ version 2.4.1 (R Development Core Team 2006). Nonlinear regressions were fitted using the 'nls' function (non-linear least squares, Bates \& Watts 1988), and GAM models were fitted using the 'gam' package (Hastie 1991).

\section{RESULTS}

Coral cover and rugosity had negligible effects on fish biomass, numbers of species, and the herbivore: carnivore ratio; however, geographical position did influence the dependent fish variables (Fig. S1, Table S1, available in the Supplement at www.int-res.com/ articles/suppl/m396p099_app.pdf). A strong secondorder polynomial relationship between latitude and both the number of fish species and the herbivore:carnivore ratio was detected. The number of fish species peaked between 5 and $15^{\circ}$, while the herbivore:carni- 
vore ratio was lowest between these latitudes. Longitude was correlated with fish biomass and number of fish, although these models were indistinguishable by the AIC method.

A comparison of GAM models for all closures and considering only compliance, size, and age found that both compliance and age were important variables for predicting fish biomass, while size and age were the best predictors for numbers of species and herbivorecarnivore biomass, respectively (Table 2). The addition of compliance to age and size models significantly increased that amount of biomass variance explained. Specifically, allowing differently shaped relationships between size and biomass for strong and variable compliance explained $47 \%$ of the variation in fish biomass. Similarly, a model that examined the interaction between reserve age and compliance explained $40 \%$ of the biomass variation, while age alone accounted for only $11 \%$. The addition of compliance to numbers of species models approximately doubled the amount of variance explained by closure size and age, although increasing the number of parameters in the models meant that these increases were not significant. Similarly, the addition of compliance to age and size models did not significantly improve the predictive capacity of herbivore-carnivore biomass.

When geographic/environmental variables were considered in models, the best combination of variables for predicting biomass was size and longitude. The best 2 variable models for numbers of species included latitude with either size or longitude, and explained 56 to $57 \%$ of the total variation. Age of closures was an important predictor of herbivore-carnivore biomass and, when combined with latitude, explained $48 \%$ of the variation. The best single-variable models of all dependent fish variables were geographic factors, but either size or age were included when 2 variables were considered.

Considering the 4 likely functional relationships for all, variable, and strong closures, the relationships between fish biomass and closure size were significant for the curvilinear models and were most robust when compliance was strong (Table 3). Fish biomass was found to increase rapidly with closure size, with maximum biomass occurring when closure sizes were between 4 and $15 \mathrm{~km}^{2}$ (Fig. 2A). When compliance was strong, the second-order polynomial model explained $\sim 90 \%$ of the variation in fish biomass with closure size. A single site, the $28 \mathrm{~km}^{2}$ Kisite Marine National Park in Kenya, largely drove the decline at the largest closure size (Fig. 2A).

Closure age was weakly and non-significantly associated with fish biomass, with the strongest relationship $\left(\mathrm{R}^{2}=0.58\right)$ associated with the second-order polynomial for the strong compliance closures (Table
3, Fig. 2B). AIC values indicated that the polynomial models were among the most parsimonious for closure size and age. A single old and small site (Cousin Island, Seychelles) largely drove both of these relationships. When removed, logarithmic and power relationships explained the same level of variation in the data.

The number of fish species was weakly and nonsignificantly related to closure size and age for all closures but more strongly associated when compli-

Table 2. Comparative influence of closure size, age, compliance, and environmental/geographic variables on fish biomass numbers of species and herbivore:carnivore biomass ratio based on the outputs of general additive model analyses. Presented are Akaike information criterion (AIC) values and deviance explained values for models considering the predictor variables of primary interest (closure age, size, and compliance), whereby compliance interacts with either age or size, allowing different-shaped relationships due to compliance. The best 1 - and 2 -variable models consider environmental/geographic factors as well as closure age, size, and compliance. See Table 1 for compliance definitions

\begin{tabular}{|c|c|c|}
\hline Variables & AIC & $\begin{array}{l}\text { Deviance } \\
\text { Explained }\end{array}$ \\
\hline \multicolumn{3}{|l|}{ Biomass } \\
\hline Size & 294.9 & 24.9 \\
\hline Age & 298.1 & 11.4 \\
\hline Compliance & 296.7 & 12.7 \\
\hline Size $\times$ Compliance & 292.6 & 46.6 \\
\hline Age $\times$ Compliance & 295.7 & 39.9 \\
\hline Size + Age & 296.9 & 24.7 \\
\hline \multicolumn{3}{|c|}{ Best single variable model } \\
\hline Longitude & 292.8 & 28.4 \\
\hline \multicolumn{3}{|l|}{ Best 2-variable model } \\
\hline Longitude + Size & 284.7 & 63.4 \\
\hline \multicolumn{3}{|l|}{ Numbers of species } \\
\hline Size & 134.0 & 10.9 \\
\hline Age & 136.2 & 0.4 \\
\hline Compliance & 136.3 & 0.2 \\
\hline Size $\times$ Compliance & 136.3 & 18.3 \\
\hline Age $\times$ Compliance & 135.8 & 25.6 \\
\hline Size + Age & 135.1 & 15.0 \\
\hline \multicolumn{3}{|c|}{ Best single variable model } \\
\hline Latitude & 125.9 & 46.0 \\
\hline \multicolumn{3}{|l|}{ Best 2-variable model } \\
\hline Latitude + Longitude & 123.2 & 57.1 \\
\hline Latitude + Size & 123.5 & 56.5 \\
\hline \multicolumn{3}{|c|}{ Herbivore - carnivore biomass } \\
\hline Size & 98.5 & 6.2 \\
\hline Age & 94.4 & 27.1 \\
\hline Compliance & 99.5 & 1.0 \\
\hline Size $\times$ Compliance & 98.9 & 29.2 \\
\hline Age $\times$ Compliance & 97.3 & 30.2 \\
\hline Size + Age & 96.4 & 26.2 \\
\hline \multicolumn{3}{|c|}{ Best single variable model } \\
\hline Latitude & 92.1 & 39.8 \\
\hline \multicolumn{3}{|l|}{ Best two variable model } \\
\hline Longitude + Latitude & 89.8 & 57.6 \\
\hline Latitude + Complexity & 90.8 & 50.2 \\
\hline Latitude + Age & 91.2 & 48.4 \\
\hline
\end{tabular}


Table 3. Influence of closure size and age on fish biomass, numbers of species, and herbivore:carnivore biomass ratio. Presented are the $\mathrm{R}^{2}$ measures and level of significance, where ${ }^{*} \mathrm{p}<0.10,{ }^{* *} \mathrm{p}<0.05$, and ${ }^{* * *} \mathrm{p}<0.01$, for linear, logarithmic (independent variable logged), power, and second-order polynomial relationships. Numbers in parentheses are Akaike information criterion (AIC) values. The most parsimonious models, based on the lowest AIC value and those models within 2 AIC units that are significant, are highlighted. See Table 1 for compliance definitions

\begin{tabular}{|c|c|c|c|c|c|}
\hline & $\mathrm{n}$ & Linear & Logarithmic & Power & Polynomial \\
\hline \multicolumn{6}{|l|}{ Fish biomass } \\
\hline \multicolumn{6}{|l|}{ Closure size } \\
\hline All closures & 20 & $0.16(295.8)^{*}$ & $0.25(293.7)^{* *}$ & $0.25(293.6)^{* *}$ & $0.27(295.2)^{*}$ \\
\hline Strong compliance & 7 & $0.18(106.9)$ & $0.60(102.0)^{* *}$ & $0.54(102.9)^{*}$ & $0.87(96.2)^{* *}$ \\
\hline Variable compliance & 13 & 0.11 (192.9) & $0.14(192.5)$ & 0.13 (192.6) & 0.11 (194.9) \\
\hline \multicolumn{6}{|l|}{ Closure age } \\
\hline All closures & 20 & $0.03(298.8)$ & $0.09(297.6)$ & $0.08(297.8)$ & $0.14(298.5)$ \\
\hline Strong compliance & 7 & $0.22(106.6)$ & $0.36(105.2)$ & $0.32(105.6)$ & $0.58(104.2)$ \\
\hline Variable compliance & 13 & $0.01(193.9)$ & $0.01(194.4)$ & $0.01(194.4)$ & $0.01(193.6)$ \\
\hline \multicolumn{6}{|l|}{ No. fish species } \\
\hline \multicolumn{6}{|l|}{ Closure size } \\
\hline All closures & 20 & $0.11(134.0)$ & $0.11(133.9)$ & $0.11(133.9)$ & $0.11(136.0)$ \\
\hline Strong compliance & 7 & $0.62(43.5)^{* *}$ & $0.69(42.1)^{* *}$ & $0.71(41.5)^{* *}$ & $0.71(41.9)^{*}$ \\
\hline Variable compliance & 13 & $0.01(91.8)$ & $0.01(91.8)$ & $0.01(91.8)$ & $0.01(93.8)$ \\
\hline \multicolumn{6}{|l|}{ Closure age } \\
\hline All closures & 20 & $0.01(136.2)$ & $0.01(136.3)$ & $0.01(136.3)$ & $0.01(137.4)$ \\
\hline Strong compliance & 7 & $0.16(49.0)$ & $0.32(47.6)$ & $0.29(47.8)$ & $0.78(41.6)^{* *}$ \\
\hline Variable compliance & 13 & $0.08(90.8)$ & $0.03(91.4)$ & $0.03(91.4)$ & $0.09(92.6)$ \\
\hline \multicolumn{6}{|c|}{ Ratio of herbivore:carnivore biomass } \\
\hline \multicolumn{6}{|c|}{ Closure size } \\
\hline All closures & 18 & $0.06(98.5)$ & $0.05(98.7)$ & $0.05(98.8)$ & $0.11(99.5)$ \\
\hline Strong compliance & 7 & $0.12(30.8)$ & $0.43(27.7)$ & $0.46(27.3)^{*}$ & $0.57(27.8)$ \\
\hline Variable compliance & 11 & $0.10(66.4)$ & $0.02(67.3)$ & $0.02(67.4)$ & $0.34(65.1)$ \\
\hline \multicolumn{6}{|l|}{ Closure age } \\
\hline All closures & 18 & $0.25(94.5)^{* *}$ & $0.22(95.2)^{*}$ & $0.18(96.2)^{*}$ & $0.30(95.3)^{*}$ \\
\hline Strong compliance & 7 & $0.30(29.2)^{*}$ & $0.58(25.6)^{* *}$ & $0.66(23.9)^{* *}$ & $0.88(18.8)^{* *}$ \\
\hline Variable compliance & 11 & $0.29(63.8)^{*}$ & $0.18(65.3)$ & $0.13(66.0)$ & $0.29(65.7)$ \\
\hline
\end{tabular}

ance was strong (Fig. 2C,D). The 4 models for strong compliance sites with size explained 60 to $70 \%$ of the variation, and AIC values were unable to differentiate among the 4 models (Table 3). A polynomial model was the best fit for numbers of species with closure age for strong compliance closures, suggesting diversity increased to a peak at 15 to $30 \mathrm{yr}$ and then declined.

When closure compliance was variable, the size and age relationships with biomass and numbers of species were weak and insignificant $(p>0.10)$. Mean biomass of fish in closures with strong compliance $(895 \pm 147 \mathrm{~kg}$ $\mathrm{ha}^{-1}$ ) was $\sim 30 \%$ more than that of closures with variable compliance $\left(624 \pm 106 \mathrm{~kg} \mathrm{ha}^{-1}\right)$. Nevertheless, the numbers of selected fish species in closures with strong $\left(24 \pm 2\right.$ spp. $\left.500 \mathrm{~m}^{-2}\right)$ and variable compliance $(24 \pm$ 2 spp. $500 \mathrm{~m}^{-2}$ ) were indistinguishable. Cousin Island stood out as an old, small, and high compliance park with low biomass and numbers of species. In contrast, Mafia Island Marine Park closure (Kitutia) had variable compliance, but had a high biomass and numbers of species for its age and size.
The ratio of herbivores to carnivores decreased with closure age and, to a lesser extent, size (Fig. 2E,F, Table 3). Closure size was only significant for the power relationship, and most of the change occurred in the first $5 \mathrm{~km}^{2}$. Compliance was not important for the age relationship, and most of the change occurred in the first $10 \mathrm{yr}$ after closure. It was impossible to distinguish between the curvilinear models for all closures, but the strong compliance closures fit best to the second-order polynomial model, due to a slight relative increase in herbivores in the oldest closures. Variable compliance closures all showed a decline in the herbivore-carnivore biomass ratio, and it was impossible to distinguish between the fit of the 3 models with declines.

\section{DISCUSSION}

Western Indian Ocean coral reef fish community measures were influenced by geography and showed weak to moderate responses for fish biomass, numbers 
of species, and herbivore-carnivore biomass ratios with the size and age of closures. The strong compliance closures largely drove the significant size and age relationships, with variable compliance closures showing essentially no response to these 2 independent attributes of closure management. Variable compliance closures elevate fish biomass above levels typically found in fished areas but do not clearly respond to time and size attributes. Compliance was also a weaker variable for relationships between closure variables and the ratio of herbivores to carnivores.

Obtaining sufficient replication of large-scale and long-term management treatments is challenging, and inadequate sample size issues can be a problem for detecting patterns with many potentially influencing variables. Significantly increasing replication in this region is not feasible, as nearly all of the active closures in the region were studied. Nevertheless, results generally support the findings of previous regional studies and contribute to an emerging view of marine closure impacts. Thirteen of the 20 fishery closures studied were categorized as having variable compliance, which is typical for the region and the world (McClanahan 1999, Wood et al. 2008). Poor compliance and a large number of interacting variables are likely to underlie the weak patterns observed in this regional and in broader meta-analyses studies (Côté et al. 2001, Halpern 2003, Micheli et al. 2004b).
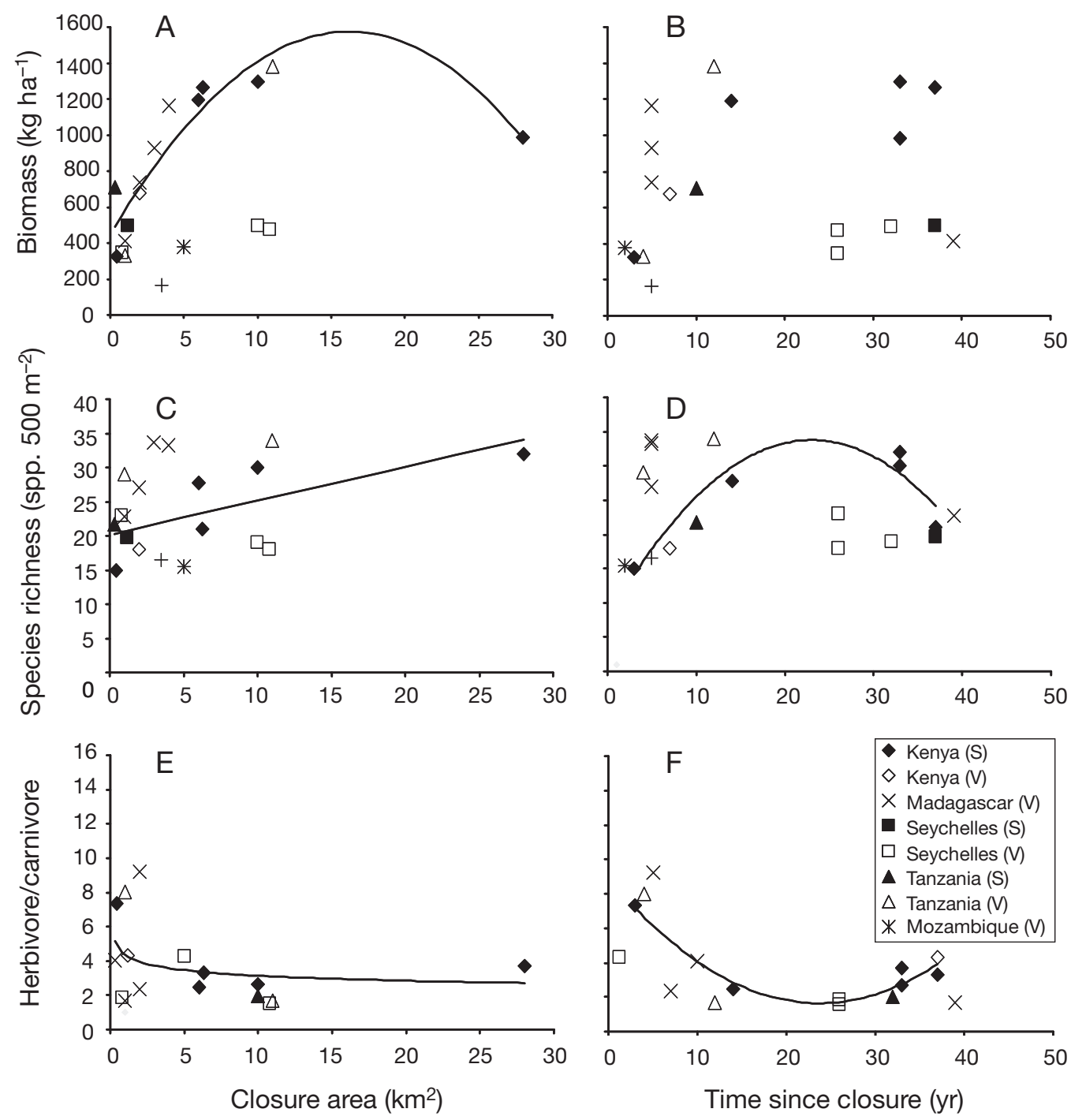

Fig. 2. Relationships between increasing closure size and age against (A, B) reef fish biomass, $(\mathrm{C}, \mathrm{D})$ numbers of species, and $(\mathrm{E}, \mathrm{F})$ ratio of herbivore to carnivore biomass in the western Indian Ocean. S: strong compliance, V: variable compliance. Lines of best fit are shown for parks of strong compliance and are based on the model with the lowest Akaike information criterion (AIC) value. No line of best fit is shown in (B), as no significant relationships were detected 
Stronger patterns have been detected in regional and single-ecosystem studies, and among closures with similar management. For example, Russ et al. (2005) studied 15 high compliance closures in the Philippines, of which the largest was $\sim 0.40 \mathrm{~km}^{2}$ and the oldest was 19 yr since closure. Predatory fish biomass increased with time in these closures but never exceeded $250 \mathrm{~kg} \mathrm{ha}^{-1}$, which is far below Pacific reefs with no history of fishing (Stevenson et al. 2007, Sandin et al. 2008). Minimal differences in the size of these small closures precluded testing for an area effect. Additionally, Claudet et al. (2008) studied 12 European marine fishery closures with a maximum size of $19 \mathrm{~km}^{2}$ and $\sim 20 \mathrm{yr}$ and found moderate responses for both factors as well as the size of the buffer zone around the closures. The emerging view from these regional studies is that size and age have measurable effects on near-shore marine closures when compliance is strong. However, geographic and site-specific differences weaken general patterns, and nearly all studies suffer from poor context when comparing findings to large remote and more pristine conditions (Knowlton \& Jackson 2008).

Despite the clear difference between strong and variable compliance closures, there are 2 examples of closures that differ from these general patterns: (1) the high biomass and numbers of species in the variable compliance Mafia and (2) low biomass in the high compliance Cousin Island closure. The 2 small private closures, Cousin and Chumbe Islands, both had high compliance. This suggests limitations in the ability of small private closures to reach the full potential for fish biomass in shallow water ecosystems, which reached $\sim 1200 \mathrm{~kg} \mathrm{ha}^{-1}$ and was mainly driven by the larger and older Kenyan closures. Maximum biomass values reported here are considerably lower than large, unfished areas of the Pacific (Letourneur et al. 2000, Friedlander \& DeMartini 2002, Stevenson et al. 2007, Sandin et al. 2008), which suggests that this 'equilibrium' is likely to be influenced by the limited size and extensive fishing in closure surroundings. A study of the lightly fished reefs of the Maldives found higher biomass and numbers of individuals and species than Kenyan closures (T. McClanahan unpubl. data), which further indicates the importance of fishing context on fishery closure effects (Côté et al. 2001, Claudet et al. 2008).

Despite the many poor relationships with closure size and age and with variable enforced closures, all closures are still likely to have responded to reduced fishing through an increase in fish biomass. The mean fish biomass in low compliance closures was $\sim 600 \mathrm{~kg}$ $\mathrm{ha}^{-1}$, which is greater than reports from heavily fished reefs in the region that seldom exceed $300 \mathrm{~kg} \mathrm{ha}^{-1}$ across a broad range of socio-economic conditions
(McClanahan et al. 1999, 2007a, Cinner et al. 2009). Even if closure regulations are not respected, our results indicate a response to closure that is significant when compared to the heavily fished areas, but not when compared to better enforced, larger, and more isolated coral reefs (McClanahan et al. 2007a, Sandin et al. 2008). Moreover, the importance of compliance is dependent on the type of fish variable being assessed. Compliance has a major influence on fish biomass within closures, but is less important when examining numbers of species. The ecological success of closures with variable compliance, even if well below the 'full potential' expected from the intensity of fishing in the surroundings, clearly highlights the need to improve links between conservation objectives (biological and ecological benefits) and coastal community livelihoods (social and economic constraints) to minimize or avoid temptations to break closure regulations (Tobey \& Torell 2006).

Both this and the Philippines study (Russ et al. 2005) suggest that small closures can enhance fish community measures above background levels of fished sites, but there are limits to their capacity. For example, a $10 \mathrm{yr}$ comprehensive ecological survey of Chumbe Island concluded that the small closure size and heavy fishing pressure in the surroundings had arrested the full ecological recovery (McClanahan et al. 2009). Indeed, the role of closure size is not clear, but it appears that closures having a surface area $>5 \mathrm{~km}^{2}$ allowed stabilization of biomass and the ratio of herbivores to carnivores.

The decrease in the ratio of herbivores to carnivores with the age of the closure suggests that herbivorous fishes dominate fished and early closure reefs. After $10 \mathrm{yr}$ without fishing, carnivorous fishes progressively increase their role in the reef processes (Schroeder \& Parrish 2005, Ledlie et al. 2007). Time series data of fish biomass recovery in closures indicate that carnivores may increase in a rapid Ricker style trajectory, whereas herbivore groups can take some time to respond and increase in a logistic pattern (McClanahan et al. 2007a). Herbivore biomass does increase, but the build-up of carnivores is likely to be more rapid and substantial (Friedlander \& DeMartini 2002). The time scale we report for this effect is similar to that reported for an increase in invertebrate-eating fish and decline of herbivorous sea urchins in Kenyan closures (McClanahan 2000), which suggests that this response may also cause species-specific prey control. Unexpectedly, this pattern was seen in all closures irrespective of closure compliance, which suggests that this ratio displays resilience to some levels of occasional fishing. Carnivorous fish are usually very sensitive to fishing pressure, and a small increase in fishing could generate a marked decrease in carnivore abundance 
and proportion of the total biomass (Jennings et al. 1995, Friedlander \& DeMartini 2002, Sandin et al. 2008). Our study found an herbivore-carnivore equilibrium at around 1-2:1 ratio, whereas remote, large, unfished reefs have reported ratios as low a 1:10 (Stevenson et al. 2007, Sandin et al. 2008). Consequently, there would appear to be considerable potential for higher carnivore biomass, and it is expected that this low level resulted from limited closure size and heavy fishing of transient predators in areas surrounding closures.

The best-fit functional responses were often those most expected for island processes where the rate of change declines and values approach levels near-equilibrium with time and size (MacArthur \& Wilson 1967). However, biomass and numbers of species did display declines with size and age of closures, respectively, resulting in an improved fit for the hump-shaped function represented by the second-order polynomial. There was also a slight increase in herbivores in some of the oldest and largest high-compliance closures. These patterns can result from changing ecological processes such as declining net productivity, competition, and predation and cascading effects (Graham et al. 2003, McClanahan \& Graham 2005, McClanahan et al. 2007a, Stockwell et al. 2009), but can also result from a sampling effect of anomalous or idiosyncratic conditions in those specific parks at the extremes of size and age. For example, one of the oldest parks was also one of the smallest (Cousin Island) and 3 of the older parks had been badly damaged by the 1998 El Niño-Southern Oscillation (Cousin Island, Malindi, and Watamu). One of the largest parks, Kisite, had a large amount of its area in sand plain habitat rather than reef, and this may have overestimated the size effect. Consequently, a variety of ecological interactions, history, local management, and resource use situations created some of the observed variability and influenced best-fit responses. At the current number of replicate closures and the large number of other potential influences, it is difficult to statistically distinguish among the many possible effects.

This study provided a single snapshot of the closures, which is useful for determining regional patterns but less so for understanding site-specific responses. The approach of presenting a single point in time for each closure was taken in order not to bias the results towards the well-sampled closures. Limited time series data are available for most of the closures in the region, with the exception of the Kenyan closures, where a more time-resolved analysis found clear patterns of recovery over the $37 \mathrm{yr}$ of closure (McClanahan et al. 2007a). The most relevant findings from the Kenyan closures study was that it took $\sim 10$ yr for species richness and $\sim 22 \mathrm{yr}$ for fish biomass to reach a maximum of $\sim 1200 \mathrm{~kg} \mathrm{ha}{ }^{-1}$. Our study includes the same closures so it cannot act as an independent evaluation of the time dynamics. Nonetheless, there is no contradiction here with the Kenyan study by the addition of more closures.

We have presented findings from a mix of community-based closures, private parks, and national programs. Small sample sizes within each of these management options precludes conclusive analyses, but the sample suggests that the small closures were usually community-based or private parks and both exhibit responses to closure but they have limited ability to achieve community measure equilibriums. National parks in Kenya had the highest biomass, but the effectiveness of national parks are countrydependent and are not always associated with high compliance and fish community variables. Clearly, geography, habitat, fishing, socio-economics, and management interact with closure design to influence fish responses (Pollnac et al. 2001, Walmsley et al. 2006, Cinner 2007, Christie \& White 2007, Cinner et al. 2009).

Acknowledgements. Research was supported by the Wildlife Conservation Society and grants from the Fisheries Society of the British Isles, Leverhulme Trust, IUCN, and Western Indian Ocean Marine Science Association (WIOMSA). This paper was derived from a WIOMSA-sponsored workshop 'People and their marine parks' organized by J. Cinner. We are grateful for logistical support from the Kenya Wildlife Service, Mauritius Oceanographic Institute, Tanga Coastal Zone Management Program, Seychelles Fishing Authority, Seychelles Centre for Marine Research and Technology - Marine Parks Authority, Nature Seychelles, Board of Trustees of the Marine Parks and Reserves of Tanzania, University of Dar es Salaam - Institute of Marine Science, and WCS-Madagascar, and we thank B.J. Radriamanantsoa, J. Maina, N.A. Muthiga, and J. Omukoto for field assistance.

\section{LITERATURE CITED}

Allen GR (2008) Conservation hotspots of biodiversity and endemism for Indo-Pacific coral reef fishes. Aquat Conserv: Mar Freshw Ecosyst 18:541-556

Allen GR, Werner TB (2002) Coral reef fish assessment in the 'coral triangle' of southeastern Asia. Environ Biol Fishes 65:209-214

Baskett ML, Micheli F, Levin SA (2007) Designing marine reserves for interacting species: insights from theory. Biol Conserv 137:163-179

Bates DM, Watts DG (1988) Nonlinear regression analysis and its applications. Wiley, New York, NY

Burnham KP, Anderson DR (2002) Model selection and multimodel inference: a practical information-theoretic approach. Springer Science, New York, NY

Christie P, White AT (2007) Best practices for improved governance of coral reef marine protected areas. Coral Reefs 26: $1047-1056$

Cinner JE (2007) Designing marine reserves to reflect socioeconomic conditions: lessons from long-enduring customary management systems. Coral Reefs 26:1035-1045 
Cinner JE, McClanahan TR, Daw TM, Graham NAJ, Maina J, Wilson SK, Hughes TP (2009) Linking social and ecological systems to sustain coral reef fisheries. Curr Biol 19: $206-212$

Claudet J, Osenberg CW, Benedetti-Cecchi L, Domenici P and others (2008) Marine reserves: size and age do matter. Ecol Lett 11:481-489

Colvocoresses J, Acosta A (2007) A large-scale field comparison of strip transect and stationary point count methods for conducting length-based underwater visual surveys of reef fish populations. Fish Res 85:130-141

Cooke AJ, Lutejeharms J, Vasseur P (2003) Marine and coastal ecosystems of Madagascar. In: Goodman S, Benstead J (eds) Natural history of Madagascar. Chicago University Press, Chicago, IL, p 179-208

> Côté IM, Mosquera I, Reynolds JD (2001) Effects of marine reserve characteristics on the protection of fish populations: a meta-analysis. J Fish Biol 59:178-189

Friedlander AM, DeMartini EE (2002) Contrasts in density, size, and biomass of reef fishes between the northwestern and the main Hawaiian islands: the effects of fishing down apex predators. Mar Ecol Prog Ser 230:253-264

Froese R, Pauly D (eds) (2008) FishBase. www.fishbase.org

- Gaylord B, Gaines SD, Siegel DA, Carr MH (2005) Marine reserves exploit population structure and life history in potentially improving fisheries yields. Ecol Appl 15: $2180-2191$

Graham NAJ, Evans RD, Russ GR (2003) The effects of marine reserve protection on the trophic relationships of reef fishes on the Great Barrier Reef. Environ Conserv 30: 200-208

> Graham NAJ, Wilson SK, Jennings S, Polunin NVC, Robinson J, Bijoux JP, Daw TM (2007) Lag effects in the impacts of mass coral bleaching on coral reef fish, fisheries, and ecosystems. Conserv Biol 21:1291-1300

Halpern B (2003) The impact of marine reserves: Do reserves work and does reserve size matter? Ecol Appl 13:117-137

Halpern BS, Warner RR (2002) Marine reserves have rapid and lasting effects. Ecol Lett 5:361-366

Halpern BS, Warner RR (2003) Matching marine reserve design to reserve objectives. Proc R Soc Lond B Biol Sci 270:1871-1878

Hastie TJ (1991) Generalized additive models. In: Chambers SJM, Hastie TJ (eds) Statistical models. Wadsworth \& Brooks/Cole, Pacific Grove, CA, p 249-307

Horrill C, Kamukuru AT, Mgaya YD, Risk M (2000) Northern Tanzania, Zanzibar and Pemba. In: McClanahan TR, Sheppard CRC, Obura DO (eds) Coral reefs of the Indian Ocean: their ecology and conservation. Oxford University Press, New York, NY, p 166-198

IUCN (2004) Managing Marine Protected Areas: a toolkit for the western Indian Ocean. International Union for the Conservation of Nature, Nairobi

> Jennings S (1998) Cousin Island, Seychelles: a small, effective and internationally managed marine reserve. Coral Reefs $17: 190$

> Jennings S, Polunin NVC (1996) Effects of fishing effort and catch rate upon the structure and biomass of Fijian reef fish communities. J Appl Ecol 33:400-412

Jennings S, Grandcourt EM, Polunin NVC (1995) The effects of fishing on the diversity, biomass and trophic structure of Seychelles' reef fish communities. Coral Reefs 14:225-235

> Jennings S, Marshall SS, Polunin NVC (1996) Seychelles' marine protected areas: comparative structure and status of reef fish communities. Biol Conserv 75:201-209

> Knowlton N, Jackson JBC (2008) Shifting baselines, local impacts, and global change on coral reefs. PLoS Biol 6:e54
Kulbicki M, Sarramégna S, Letourneur Y, Wantiez L and others (2007) Opening of an MPA to fishing: natural variations in the structure of a coral reef fish assemblage obscure changes due to fishing. J Exp Mar Biol Ecol 353: 145-163

Ledlie MH, Graham NAJ, Bythell JC, Wilson SK, Jennings S, Polunin NVC, Hardcastle J (2007) Phase shifts and the role of herbivory in the resilience of coral reefs. Coral Reefs 26:641-653

Leslie H, Ruckelshaus M, Ball IR, Andelman S, Possingham HP (2003) Using siting algorithms in the design of marine reserve networks. Ecol Appl (Suppl) 13:185-198

> Lester SE, Halpern BS, Grorud-Colvert K, Lubchenco J and others (2009) Biological effects within no-take marine reserves: a global synthesis. Mar Ecol Prog Ser 384:33-46

Letourneur Y, Kulbicki M, Labrosse P (1998) Length-weight relationships of fish from coral reefs and lagoons of New Caledonia. An update. Naga ICLARM Q 21:39-46

Letourneur Y, Kulbicki M, Labrosse P (2000) Fish stock assessment of the northern New Caledonian lagoons: 1 Structure and stocks of coral reef fish communities. Aquat Living Resour 13:65-76

MacArthur RH, Wilson EO (1967) The theory of island biogeography. Princeton University Press, Princeton, NJ

> MacNeil MA, Graham NAJ, Conroy MJ, Fonnesbeck CJ and others (2008) Detection heterogeneity in underwater visual-census data. J Fish Biol 73:1748-1763

Maina J, Venus V, McClanahan TR, Ateweberhan M (2008) Modelling susceptibility of coral reefs to environmental stress using remote sensing data and GIS models. Ecol Model 212:180-199

McClanahan TR (1994) Kenyan coral reef lagoon fish: effects of fishing, substrate complexity, and sea urchins. Coral Reefs 13:231-241

McClanahan TR (1999) Is there a future for coral reef parks in poor tropical countries? Coral Reefs 18:321-325

McClanahan TR (2000) Recovery of a coral reef keystone predator, Balistapus undulates, in East African marine parks. Biol Conserv 94:191-198

McClanahan TR, Graham NAJ (2005) Recovery trajectories of coral reef fish assemblages within Kenyan marine protected areas. Mar Ecol Prog Ser 294:241-248

McClanahan TR, Kaunda-Arara B (1996) Fishery recovery in a coral-reef marine park and its effect on the adjacent fishery. Conserv Biol 10:1187-1199

McClanahan TR, Obura DO (1996) Coral reefs and nearshore fisheries. In: McClanahan TR, Young TP (eds) East African ecosystems and their conservation. Oxford University Press, New York, NY, p 67-99

> McClanahan TR, Muthiga NA, Kamukuru AT, Machano H, Kiambo RW (1999) The effects of marine parks and fishing on coral reefs of northern Tanzania. Biol Conserv 89: 161-182

> McClanahan TR, Marnane MJ, Cinner JE, Kiene W (2006a) A comparison of Marine Protected Areas and alternative approaches to coral reef management. Curr Biol 16: $1408-1413$

McClanahan TR, Verheij E, Maina J (2006b) Comparing management effectiveness of a marine park and a multipleuse collaborative fisheries management area in East Africa. Aquat Conserv: Mar Freshw Ecosyst 16:147-165

> McClanahan TR, Graham NAJ, Calnan JM, MacNeil MA (2007a) Towards pristine biomass: reef fish recovery in coral reef marine protected areas in Kenya. Ecol Appl 17:1055-1067

> McClanahan TR, Graham NAJ, Maina J, Chabanet P, Bruggemann JH, Polunin NVC (2007b) Influence of 
instantaneous variation on estimates of coral reef fish populations and communities. Mar Ecol Prog Ser 340: 221-234

McClanahan TR, Muthiga NA, Maina J, Kamukuru AT, Yahya S (2009) Changes in northern Tanzania coral reefs over a period of increased fisheries management and climatic disturbance. Aquat Cons: Mar Freshw Ecosyst 19: 758-771

Micheli F, Amarasekare P, Bascompte J, Gerber LR (2004a) Including species interactions in the design and evaluation of marine reserves: some insights from a predatorprey model. Bull Mar Sci 74:653-669

Micheli F, Halpern BS, Botsford LW, Warner RR (2004b) Trajectories and correlates of community change in no-take marine reserves. Ecol Appl 14:1709-1723

Munday PL (2002) Does habitat availability determine geographical-scale abundances of coral-dwelling fishes? Coral Reefs 21:105-116

Ortiz DM, Tissot BN (2008) Ontogenetic patterns of habitat use by reef-fish in a Marine Protected Area network: a multi-scaled remote sensing and in situ approach. Mar Ecol Prog Ser 365:217-232

Pollnac RB, Crawford BR, Gorospe MLG (2001) Discovering factors that influence the success of community-based marine protected areas in the Visayas, Philippines. Ocean Coast Manage 44:683-710

R Development Core Team (2006) R: a language and environment for statistical computing. R Foundation for Statistical Computing, Vienna. Available at: www.R-project.org

Risk MJ (1972) Fish diversity on a coral reef in the Virgin Islands. Atoll Res Bull 153:1-6

Roberts CM, Halpern B, Palumbi SR, Warner RR (2001) Designing marine reserve networks. Conserv Biol Pract 2:11-17

Rodwell L, Barbier EB, Roberts CM, McClanahan TR (2002) A model of tropical marine reserve-fishery linkages. Nat Resour Model 15:453-486

Rosenzweig ML (1995) Species diversity in space and time. Cambridge University Press, New York, NY

Rothley KD (1999) Designing bioreserve networks to satisfy multiple, conflicting demands. Ecol Appl 9:741-750

Russ GR (2002) Yet another review of marine reserves as reef fishery management tools. In: Sale PF (ed) Coral reef fishes, dynamics and diversity in a complex ecosystem. Academic Press, San Diego, CA, p 421-443

Russ GR, Alcala AC (2004) Marine reserves: long-term protection is required for full recovery of predatory fish populations. Oecologia 138:622-627

Russ GR, Stockwell B, Alcala AC (2005) Inferring versus measuring rates of recovery in no-take marine reserves. Mar Ecol Prog Ser 292:1-12

Editorial responsibility: Charles Birkeland, Honolulu, Hawaii, USA
Sala E, Aburto-Oropeza O, Paredes G, Para I, Barrera JC, Dayton PK (2002) General model for designing networks of marine reserves. Science 298:1991-1993

Sale PF, Cowen RK, Danilowicz BS, Jones GP, and others (2005) Critical science gaps impede use of no-take fishery reserves. Trends Ecol Evol 20:74-80

> Samoilys MA, Carlos G (2000) Determining methods of underwater visual census for estimating the abundance of coral reef fishes. Environ Biol Fishes 57:289-304

Sandin SA, Smith JE, DeMartini EE, Dinsdale EA, and others (2008) Baselines and degradation of coral reefs in the northern Line Islands. PLoS One 3:e1548

Schroeder RE, Parrish JD (2005) Resilience of predators to fishing pressure on coral patch reefs. J Exp Mar Biol Ecol 321:93-107

Shanks AL, Grantham BA, Carr MH (2003) Propagule dispersal distance and the size and spacing of marine reserves. Ecol Appl (Suppl) 13:159-169

Sladek Nowlis J, Roberts CM (1999) Fisheries benefits and optimal design of marine reserves. Fish Bull 97:604-616

> Stevenson C, Katz LS, Micheli F, Block BA and others (2007) High apex predator biomass on remote Pacific islands. Coral Reefs 26:47-51

Stockwell B, Jadloc CRL, Abesamis RA, Alcala AC, Russ GR (2009) Trophic and benthic responses to no-take marine reserve protection in the Philippines. Mar Ecol Prog Ser 389:1-15

Tobey J, Torell E (2006) Coastal poverty and MPA management in mainland Tanzania and Zanzibar. Ocean Coast Manage 49:834-854

Walley CJ (2004) Rough water: nature and development in an East African marine park. Princeton University Press, Princeton, NJ

> Walmsley S, Purvisa J, Ninnes C (2006) The role of smallscale fisheries management in the poverty reduction strategies in the Western Indian Ocean region. Ocean Coast Manage 49:812-833

Watson RA, Quinn TJ (1997) Performance of transect and point count underwater visual census methods. Ecol Model 104:103-112

> Williams ID, Walsh WJ, Tissot BN, Hallacher LE (2006) Impact of observers' experience level on counts of fishes in underwater visual surveys. Mar Ecol Prog Ser 310:185-191

Wilson SK, Graham NAJ, Polunin NVC (2007) Appraisal of visual assessments of habitat complexity and benthic composition on coral reefs. Mar Biol 151:1069-1076

Wood I (2004) Motives for poaching in marine protected areas in the Seychelles. Western Indian Ocean J Mar Sci 3: 199-208

Wood LJ, Fish L, Laughren J, Pauly D (2008) Assessing progress towards global marine protection targets: shortfalls in information and action. Oryx 42:340-351

Submitted: April 1, 2009; Accepted: August 22, 2009

Proofs received from author(s): November 17, 2009 